\title{
FORTY-NINTH AND FIFTIETH ANNUAL REPORTS OF THE STATE GEOLOGIST
}

Iowa Geological Survey

Iowa City, Iowa

Decèmber 31, 1941

To Governor George A. Wilson and Members of the Geological Board:

Gentlemen :

The following report covering the calendar years 1940 and 1941 and four accompanying papers are submitted with the recommendation that they be published as Volume XXXVIII of the Annual Reports of the Iowa Geological Survey.

During these two years the program was carried forward much the same as formerly but with some changes in the emphasis. In general, the policy is to give increasing attention to those studies and services that permit practical, direct and prompt return to the tax-paying public of the State in the form of information, advice and help in the development of water supplies and other domestic and industrial raw materials.

At this date the great war in Europe, Asia and Africa has. been in progress for more than two years and American participation in a world war for twenty-five days. With the inauguration of selective service in the autumn of 1940 and the development of war industries, new and increased demands appeared for geological information and guidance both in the preparedness and direct war programs and for the expansion of war industries. These demands will doubtless grow in frequency and urgency as the war progresses and for its duration.

More specifically the various activities are as follows:

\section{Well Water Supplies}

Studies and services connected with the production of underground water through wells continue to constitute the largest and most important single part of the program. In 1941 more than sixty percent of the funds, personnel and program were devoted to geological work on the development of well water supplies for domes- 
tic, industrial, and war uses. Information, advice and direct help are given as new wells are considered, planned for, located, drilled. and used. Such service to cities, towns, state parks, peace-time industries, and individuals is being continued. Recently similar service has been extended to problems of development of much larger sapplies of well water for training camps, munitions plants, air bases and expanded food and war materials producing industries.

The geological aspects of this work are done or directed by Dr. H. G. Hershey, Assistant State Geologist. He is assisted by K. E. Anderson, Junior Geologist, D. A. Davis and J. B. Carrier, geological assistants, and several part-time student assistants. Unfortunately the mineral analysis of well water from different geologisal sources has had to be abandoned, temporarily it is hoped, because of lack of funds and personnel, both of which were formerly supplied from the Work Projects Administration.

By a continuation and expansion of cooperative agreements with the Ground Water Division of the Water Resources Branch of the U. S. Geological Survey under Mr. T. W. Robinson, Engineer, assisted by A. P. Gerardi, Junior Engineer, the study of water pumpages, levels and reserves has made considerable progress. At the end of 1941 there were 262 observation wells in operation. It is probable that some of the Iowa underground reserves are being overpumped and depleted. As this program gets older and data accumulate the development of new and inereased water. supplies can be accomplished more intelligently than has been possible previously.

Several of the states have enacted legislation designed to place the planning, locating, drilling, and abandoning of wells under State regulation. The Geological Survey together with the Department of Health, the Conservation Commission, the Iowa Water Well Drillers Association, and some of the consulting engineers of the Iowa Engineering Society, and with the advice and criticism of ground-water experts of the U. S. Geological Survey has given considerable attention to such legislation for this State. The idea is to improve the well water supplies, to avoid waste, and to reduce unnecessary "costs.

\section{Stream and Lake Gaging}

Cooperation with the Surface Water Division of the Water Resources Branch of the United States Geological Survey in a stream and lake gaging progxam has been continued. The main purpose is 
to secure, record, and supply data on low flow, flood flow and average annual flow of Iowa streams and of low, high and average stages in the more important Iowa lakes. There is an increasing demand for these data from those engaged in projects of flood control, soil erosion prevention, navigation, recreation, power development, water supply, stream pollution, fish and game, silting, weather statistics, designing bridges, culverts, dams, etc.

Since early in 1940 when R. G. Kasel was called to Washington to take charge of stream gaging in all of the states, the Iowa program has been directed by L. C. Crawford, District Engineer of the U. S. Geological Survey. $\mathrm{He}$ is assisted by a number of engineers of varying Civil Service rating and a few non-Civil Service men. At present 71 stream gaging stations are in operation and 10 lake stations. This represents an increase of 7 stream stations since the last report on December 31, 1939. The mass of information concerning the surface water supplies of the State is coming to be respectable in quantity and quality. Its value and usefulness depend largely on the length of time during which records are kept and on continuity of recording. Now that a good start has been made on keeping continuous records, the program should be continued without interruption by all means and it should be expanded if possible.

\section{Oil and Gas}

Since the last report two years ago a considerable amount of geological and geophysical exploratory work on oil and gas has been done by major and minor oil companies and seven tests have been drilled. All but one reached their objectives and were abandoned as dry holes. One other is still drilling on this date. Unfortunately so far no oil or gas in commercial quantities has been discovered.

All of these tests were made in southwestern Iowa in the northern portion of the Forest City Basin where geological conditions are considered to be more favorable than elsewhere in the State. One test was made in Union County, three in Taylor County, one in Fremont County, and two in Montgomery County.

The operators of these drillings complied in all respects with the law (48th G. A., Senate File 328) and welcomed the cooperation of the Geological Survey far beyond the legal requirements. Once locations were announced along,with the notification of intention to drill, state geologists forecast the depths at which possible producing formations would be reached, agreed with operators and drillers concerning the taking of drilling samples, watched much of 
the drilling directly, made laboratory studies of the samples, kept running geological logs, and gave advice concerning casing seats, sampling and shutting off of waters from different depths, testing different formations for oil, and final abandonment and plugging. All information so gained was of course held in strict confidence until release by the operator.

It is probable that the test now drilling will be completed and that other tests will be made at other locations. It is still too early to determine that Iowa either will or will not eventually produce oil or gas in commercial quantities.

\section{Coal Bearing Beds}

Work on the rock formations with which Iowa coal beds are associated which was started in 1932 is nearing. completion or at least the point of diminishing returns. Papers by Professor A. C. Tester of the University and D. S. Stookey formerly a graduate student at the Unversity and by Professor L. M. Cline of the State College and D. S. Stookey, it is hoped, will be finished and submitted within the next few months. The results of this work include clearer and better ideas of how these beds and the associated coals were deposited originally and what changes they have undergone since their deposition, more knowledge of the thickness and persistence of the coal beds and correlations of the Iowa strata with similar beds in Missouri on the south and Illinois on the east.

Dr. H. L. Olin, Professor of Chemical Engineering at the University, has continued his studies of the properties of Iowa coals and has completed a manuscript on "The Preparation of Stoker Coals from Iowa Screenings" which will be published soon as University of Iowa Studies in Engineering, Bulletin 28.

It is believed that the Iowa coal industry is in position to meet any demands for increased production that may be brought about by the promotion of the war; provided legislation is not unfavorable.

\section{Pleistocene Geology}

Dean George F. Kay assisted-by Jack B. Graham, a graduate student in the University has completed Part II of an exhaustive work on the glacial or Pleistocene Geology of Iowa. This paper published in this volume will be of practical use in the mapping, interpretation and use of soils, in the prevention of soil erosion, in the never-ending search for sand and gravel deposits, and in the study of and service on shallow wells that supply water from glacial or interglacial materials. 


\section{Shales and Clays}

Professor C. S. Gwynne has completed several years of work on the shales and clays of the State and his paper entitled "Ceramic Shales and Clays of Iowa" appears farther along in this volume. This paper should be of interest and value to operators of brick and tile and cement plants.

In cooperation with the State College departments of geology under Professor John T. Lonsdale and ceramic engineering under Professor C. M. Dodd, investigations were started to determine the properties of and if possible to find uses for the underclays that occur beneath most of the Iowa coal beds. The time of Mr. G. D. Monk was contributed by the Department of Geology at Ames and his field work was supervised by Professor L. M. Cline; the Geological Survey paid the field expenses; and tests of underclays collected by him are being carried out under the direction of Professor Dodd. At this time the work is incomplete.

\section{Agricultural Lime Surveys}

Only one additional county has been surveyed for agricultural lime since the last report. At the request of the Agricultural Adjustment Administration Soil Conservation Association in Lee County a special survey of the agricultural lime resources was undertaken. At the expense of the Geological Survey the field work was done by Clifford Adams. Invaluable help was given by Delbert T. Foster, County Agricultural Agent who gave office space in the Court House for Mr. Adams and handled the samples, and by members of the County Soil Conservation Committee who aided in locating exposures in the field. The samples were analyzed for carbonate content under the direction of Professor B. J. Firkins of the Department of Agronomy at the State College. A report was prepared and made available to interested parties in Lee County.

The amount of agricultural lime that could be used to advantage on Iowa land is almost unlimited. The amount and purity of limestone available, the thickness and character of overburden, the cost of crushing and the distance and cost of transportation from quarry source to land to be limed are all factors.

The location, sampling and determination of overburden can best be done by geologists. The Geological Survey should probably give more service along this line in the future. 


\section{Mineral Production}

Figures on mineral production are being collected as usual in cooperation with the U. S. Bureau of Mines. "Mineral Production in Iowa in 1939 and 1940 " by H. G. Hershey is published in this volume.

\section{Other Activities}

No further progress has been made during the last two years with the preparation of county reports. Audubon, Floyd, Greene, and Union Counties have been surveyed but the reports and maps await checking and revision, and Calhoun and Shelby Counties still remain to be surveyed. Otherwise the 99 counties have been surveyed and the reports have been published.

Study of the "Cambrian Strata of Northeastern Iowa" by Walter C. Schuldt has been completed and the results are published under this title and authorship in this volume.

Past attempts to locate raw material for the manufacture of rock wool and to encourage manufacturers to locate plants in Iowa have not been successful to date. The one existing plant in Iowa secures its raw material from outside the State. A large plant which it was hoped would be located in lowa finally went to Minnesota where it is located near an important market.

Respectfully submitted,

'Arthur C. Trowbridge

Director and State Geologist 